\title{
Optimization of upstream and downstream process parameters for cellulase-poor-thermo- solvent-stable xylanase production and extraction by Aspergillus tubingensis FDHN1
}

\author{
Dharmesh N Adhyaru', Nikhil S Bhatt ${ }^{1 *}$ and Hasmukh A Modi
}

\begin{abstract}
Background: Xylanases are important members of the hemicellulolytic enzyme system. Xylanase plays a vital role in the hydrolysis of major hemicellulosic component xylan and converts it into xylooligosaccharides and ultimately yields xylose. Cellulase-lacking or cellulase-poor xylanase with high temperature and pH stability has gained special attention, especially in paper and pulp industries. Most of the available literature highlighted the fungal xylanase production by optimizing environmental and cultural parameters. However, the importance of enzyme recovery from fermented biomass still needs attention. In this study, upstream and downstream process parameters were studied for enhancing xylanase production and extraction by a newly isolated Aspergillus tubingensis FDHN1 under solid-state fermentation using low-cost agro-residues.
\end{abstract}

Results: In the present study, A. tubingensis FDHN1 was used for the xylanase, with very low level of cellulase, production under solid-state fermentation (SSF). Among various agro-residues, sorghum straw enhanced the xylanase production. Under optimized upstream conditions, the highest xylanase production 2,449 $\pm 23 \mathrm{U} / \mathrm{g}$ was observed. Upon characterization, crude xylanase showed stability over a broad range of pH 3.0 to 8.0 up to $24 \mathrm{~h}$. The temperature stability revealed the nature of the xylanase to be thermostable. Native polyacrylamide gel electrophoresis (native PAGE) and zymogram analysis revealed the multiple forms of the xylanase. Due to the many industrially important characteristics of the xylanases, the study was elaborated for optimizing the downstream process parameters such as volume of extractant, extraction time, temperature and agitation speed to recover maximum xylanase from fermented sorghum straw. The highest amount of xylanase $(4,105 \pm 22 \mathrm{U} / \mathrm{g})$ was recovered using $0.05 \mathrm{M}$ sodium citrate buffer ( $\mathrm{pH}$ 6.5) at 12:1 ( $/ \mathrm{W}$ ) extractant/solid ratio, 90-min extraction time, 150-rpm agitation speed and $40^{\circ} \mathrm{C}$. Finally, detailed bioprocess optimization shows an overall 6.66-fold enhancement in the xylanase yield.

Conclusions: The present study consolidates the importance of upstream and downstream process optimization for the overall enhancement in the xylanase production. The xylanase from A. tubingensis FDHN1 shows the stability at different $\mathrm{pH}$ and temperature, and it was also active in the presence of organic solvents. These properties of xylanase are very much important from an industrial application point of view.

Keywords: Cellulase-poor xylanase; Upstream-downstream process optimization; Aspergillus tubingensis FDHN1; Solid-state fermentation; Thermo-solvent stable enzyme; Multiple xylanases

\footnotetext{
* Correspondence: bhattnikhil2114@gmail.com

'P. G. Department of Microbiology, Gujarat Vidyapeeth, M. D. Gramseva

Mahavidhyalaya, Talim Kendra Campus, Sadra 382 320, Gujarat, India

Full list of author information is available at the end of the article
} 


\section{Background}

Hemicelluloses are the second most abundant renewable resources, only exceeded by cellulose. Xylan constitutes a major component of hemicellulose, which is a heteropolysaccharide, having a chain of $\beta-1,4$-linked xylopyranose residues. The complete hydrolysis of xylan requires the combined action of various enzymes such as endo $\beta$-1,4-xylanase (E.C. 3.2.1.8), exoxylanase ( $\beta$-D-xylan xylohydrolase), $\beta$-D-xylosidase (E.C. 3.2.1.37), etc. [1,2]. Recently, xylanases have attracted considerable attention due to its application in many industrial processes such as enzymatic bleaching of paper pulp, juice clarification, extraction of plant oils, texture improvement in bakery, bioconversion of agricultural waste, bioscouring in textiles and improvement of animal feed digestibility [3-5]. Due to such immense industrial applications, xylanases have a worldwide market of around 200 million dollars.

Filamentous fungi are good producers of xylanase because they are capable of producing high levels of extracellular enzymes and can be cultivated very easily. On an industrial scale, xylanases are mainly produced by Aspergillus and Trichoderma sp. in solid-state fermentation (SSF). The research has indicated that xylanase production differs with the strains and is regulated by physiological, nutritional and biochemical nature of the microbes employed [6]. The fermentation profile of an organism that influences metabolism-mediated production includes $\mathrm{pH}$, temperature, carbon and nitrogen source, metal ion requirement, incubation time, inoculum size, etc. The production of an industrial enzyme by optimizing these growth parameters is of prime importance because an improper optimization of these factors may result in the lower enzyme production. In general, no defined medium has been established for the best production of any metabolite because the genetic diversity present in different microbial sources causes each organism or strain to have its own special conditions for maximum product yield [7]. For the commercialization of xylanase production, it is necessary to identify a microorganism that produces high levels of xylanase using cheaper carbon sources and having novel properties. As lignocellulosic materials are abundantly found in nature in the form of agricultural and industrial residues, it can be exploited as a potential substrate for growing the organisms.

Apart from medium optimization, recovery of enzyme is also an important aspect of SSF technology. An optimized recovery process would generate concentrated enzyme extract, prevent enzyme loss, reduce the number of the downstream process step and thus gain better commercial viability. A wealth of information is available on medium optimization for xylanase production [8-11], but studies on xylanase recovery from fermented substrate are scarce [11]. Therefore, it is highly imperative to optimize production and extraction parameters which further facilitate economic design of the full-scale operation system for newly isolated microbial strains.

In the present study, we have highlighted the optimization of upstream process for xylanase production using newly isolated Aspergillus tubingensis FDHN1 under SSF. Produced xylanase was characterized for important properties such as $\mathrm{pH}$, temperature and solvent tolerance. Looking towards the important features of this xylanase and thrust for its higher yield, downstream process parameters for xylanase recovery were also optimized.

\section{Methods}

Agro-residue preparation, chemicals and medium components Different agro-residues such as caster straw, wheat straw, maize straw, rice straw, sorghum straw, barley straw, sugarcane bagasse, wood chips and groundnut shell were collected locally from agricultural farms. To remove the adhered surface dust particles, agro-residues were washed in distilled water, dried at $50^{\circ} \mathrm{C}$ and chopped into small pieces. These were ground in mixture to achieve average particle size of 0.5 to $2 \mathrm{~mm}$.

Chemicals such as oat spelt xylan, carboxymethyl cellulose (CMC), bovine serum albumin (BSA) and dinitrosalicylic acid (DNSA) were purchased from HiMedia Laboratories Ltd (Mumbai, India). All the other chemicals, media, salts and reagents used were of analytical grade (Sigma-Aldrich, St. Louis, MO, USA; HiMedia, Mumbai, India; and Merck \& Co., Inc., Whitehouse Station, NJ, USA).

\section{Fungal isolation, identification and inoculum preparation}

The novel cellulase-poor xylanase-producing fungal strain FDHN1 was isolated in our laboratory from active compost pit (approximately 10-cm depth). The strain was identified at the National Fungal Culture Collection of India (NFCCI), Pune, India, on the basis of morphological and molecular study. The strain was identified as A. tubingensis. Morphologically, the strain showed white velvety colonies which later turns to greyish-black on potato dextrose agar (PDA) plates. Under stereoscopic observation, the conidial heads were found to be globose, radiating, split into columns, greyish metallic in colour and measured up to $260 \times 260 \mu \mathrm{m}$ in size. The conidiophores were found to be hyaline to subhyaline which later turned into brown when old, smooth-walled and up to $625 \times 5 \mu \mathrm{m}$ in size. The vesicles were globose to subglobose, fertile all over and up to $39.0 \times 45.5 \mu \mathrm{m}$ in size. $18 \mathrm{~S} \mathrm{rDNA}$ gene sequence of fungus has been submitted to NCBI (Accession No. KF971693).

Spore inoculum was prepared from 5-day grown culture on PDA slants at $35^{\circ} \mathrm{C}$. Suspension was prepared by lightly brushing the slant containing fungal mycelia with sterile distilled water to give a final spore count of approximately $1 \times 10^{6}$ spores $/ \mathrm{mL}$. 


\section{Xylanase production using agro-residues and upstream process optimization}

Caster straw, wheat straw, maize straw, rice straw, sorghum straw, barley straw, groundnut shell, sugarcane bagasse and wood chips were used as substrates to produce xylanase under SSF. Erlenmeyer flasks $(250 \mathrm{~mL}$ ) containing $5 \mathrm{~g}$ of each substrates and $5 \mathrm{~mL}$ of mineral salt medium $\left(\mathrm{g} \mathrm{L}^{-1}: \mathrm{KH}_{2} \mathrm{PO}_{4}, 3.0 ; \mathrm{NaNO}_{3}, 2.5 ; \mathrm{MgSO}_{4}\right.$. $7 \mathrm{H}_{2} \mathrm{O}, 1.0 ; \mathrm{CaCl}_{2}, 0.05 ; \mathrm{FeSO}_{4} \cdot 7 \mathrm{H}_{2} \mathrm{O}, 7.5 ; \mathrm{MnSO}_{4}, 2.5$; $\mathrm{ZnSO}_{4} \cdot 7 \mathrm{H}_{2} \mathrm{O}, 3.6 ; \mathrm{CoCl}_{2} \cdot 6 \mathrm{H}_{2} \mathrm{O}, 3.0$ and $0.1 \%$ Tween$\left.80\left(v \cdot v^{-1}\right), \mathrm{pH} 5.0\right)$ were autoclaved at $121^{\circ} \mathrm{C}$ for $15 \mathrm{~min}$, cooled, inoculated with $1 \mathrm{~mL}$ of spore suspension and incubated at $35^{\circ} \mathrm{C}$ for 6 days.

SSF conditions were optimized by changing one factor at a time while keeping the other factors constant. To improve xylanase production, various upstream process parameters such as sorghum straw concentration (3.0 to $15 \mathrm{~g}$ ), incubation period ( 2 to 8 days), substrate to moisture ratio (1:1 to $1: 7 w / v)$, medium $\mathrm{pH}(3.0$ to 9.0$)$ and temperature $\left(25\right.$ to $\left.55^{\circ} \mathrm{C}\right)$ were optimized. Furthermore, effect of various carbon sources (glucose, fructose, sucrose, xylose, lactose, maltose and mannitol at $0.5 \%$ concentration), organic nitrogen sources (peptone, beef extract, urea, yeast extract, tryptone, malt extract, meat extract, gelatine and skimmed milk powder at $0.05 \mathrm{~g}$ ' $\mathrm{N}$ ' equivalent in $50 \mathrm{~mL}$ medium) and inorganic nitrogen sources (ammonium hydrogen phosphate, ammonium dihydrogen phosphate ammonium sulphate, ammonium per sulphate, ammonium nitrate, ammonium chloride and sodium nitrate at $0.05 \mathrm{~g}$ ' $\mathrm{N}$ ' equivalent in $50 \mathrm{~mL}$ medium) were evaluated for xylanase production. The xylanase production was also assessed in the presence of different metal additives $\left(\mathrm{CuCl}_{2}, \mathrm{MgCl}_{2}, \mathrm{SnCl}_{2}, \mathrm{CaCl}_{2}\right.$, $\mathrm{HgCl}_{2}, \mathrm{CoCl}_{2}, \mathrm{MnCl}_{2}, \mathrm{NiCl}_{2}$ and $\mathrm{FeCl}_{3}, 0.2 \%$ ) and modulators (Tween-40, Tween-80, Triton X-100, glycine, glycerol, EDTA and SDS, $0.1 \%$ ).

\section{Enzyme assay and protein estimation}

Xylanase activity was determined by adopting the modified method of Bailey et al. [12]. The reaction mixture containing $450 \mu \mathrm{L}$ of oat spelt xylan (1\%) prepared in $0.05 \mathrm{M}$ citrate buffer ( $\mathrm{pH} 5.0$ ) and $50 \mu \mathrm{L}$ of enzyme was incubated at $55^{\circ} \mathrm{C}$ for $10 \mathrm{~min}$. The reaction was stopped by adding $2 \mathrm{~mL}$ of DNSA. The mixture was then heated in boiling water bath for $10 \mathrm{~min}$ and cooled down to room temperature, and then, $3 \mathrm{~mL}$ of water was added to the system. CMCase activity was assayed according to the method of Ghose [13]. The reaction system containing $1,000 \mu \mathrm{L}$ of $\mathrm{CMC}(1 \%)$ dissolved in $0.05 \mathrm{M}$ citrate buffer ( $\mathrm{pH} 5.0$ ) and $500 \mu \mathrm{L}$ of enzyme was incubated at $60^{\circ} \mathrm{C}$ for $60 \mathrm{~min}$. After incubation, $3 \mathrm{~mL}$ of DNSA was added to the system followed by 10 -min incubation in a boiling water bath. The absorbance of the colour developed during xylanase and cellulase assay was measured at $540 \mathrm{~nm}$ as described by Miller [14]. One unit of xylanase/cellulase activity was defined as the amount of enzyme required to liberate $1 \mu \mathrm{mol}$ of xylose/glucose equivalent per minute under the specified conditions. The unit ' $\mathrm{U} / \mathrm{g}$ ' denotes the xylanase/cellulase activity in international unit per gram dry substrate.

Soluble protein was determined by Folin's method using bovine serum albumin as standard [15].

\section{Enzymatic properties of crude xylanase}

The $\mathrm{pH}$ optima for xylanase activity was determined by measuring its activity in various buffers $(0.05 \mathrm{M})$ such as sodium citrate ( $\mathrm{pH} 3.0$ to 6.0), sodium phosphate ( $\mathrm{pH}$ 6.0 to 8.0$)$ and glycine- $\mathrm{NaOH}(\mathrm{pH} 8.0$ to 10$)$. The $\mathrm{pH}$ stability of xylanase was studied by incubating it in the above buffers for $24 \mathrm{~h}$, and its residual activity was determined at a regular interval of $3 \mathrm{~h}$.

The optimal temperature for xylanase activity was determined by assaying its activity at different temperatures $\left(30\right.$ to $70^{\circ} \mathrm{C}$ ). The thermostability of xylanase was determined at 30 to $70^{\circ} \mathrm{C}$ by measuring its activity at a regular interval of $30 \mathrm{~min}$ up to $120 \mathrm{~min}$.

The solvent stability of xylanase was assessed by incubating the enzyme in the presence of various organic solvents (methanol, ethanol, propanol, butanol, acetone and benzene, at 10 to $30 \%$ concentration) for $30 \mathrm{~min}$, and at the end of the reaction, residual activity was measured.

\section{Native PAGE and xylan zymography}

Native polyacrylamide gel electrophoresis (native PAGE) of the crude enzyme extract was performed at room temperature using $0.05 \mathrm{M}$ citrate buffer ( $\mathrm{pH}$ 5.0). The electrophoresed gel was stained with Coomassie Brilliant Blue G-250 for molecular weight determination [16]. A replica gel containing xylan $(0.5 \%)$ was incubated at $50^{\circ} \mathrm{C}$ for $5 \mathrm{~min}$ in buffer and then stained in $0.1 \%$ Congo Red solution. After removal of dye using $1 \mathrm{M} \mathrm{NaCl}$, gel was transferred to $5 \%$ acetic acid solution. Clear bands against a dark background indicated xylanase activity.

\section{Enzyme extraction and downstream process optimization}

Initially, the xylanase extraction was performed using $0.05 \mathrm{M}$ citrate buffer ( $\mathrm{pH}$ 5.0) at an extractant/solid ratio of 10:1 $(\mathrm{v} / \mathrm{w})$. Next, the suspension was agitated at $120 \mathrm{rpm}$ for $60 \mathrm{~min}\left(35^{\circ} \mathrm{C}\right)$, centrifuged at $10,000 \times g$ for $15 \mathrm{~min}\left(4^{\circ} \mathrm{C}\right)$ and finally the clear supernatant was used as a crude enzyme source.

In order to find the most suitable extractant for xylanase recovery from fermented sorghum straw, seven different solvents $(0.05 \mathrm{M}$ citrate buffer, $\mathrm{pH} 5.0 ; 0.05 \mathrm{M}$ sodium citrate buffer, $\mathrm{pH} 6.5$; double-distilled water, $\mathrm{pH}$ 7.0; 0.05 M phosphate buffer, $\mathrm{pH} 7.5 ; 0.05 \mathrm{M}$ Tris- $\mathrm{HCl}$ buffer, $\mathrm{pH}$ 8.0; $0.1 \%$ Tween-80 and $1.0 \% \mathrm{NaCl}$ ) at an 
extractant/solid ratio of 10:1 $(v / w)$ were used. After selecting extractant type, different recovery parameters such as extractant/solid ratio $(4: 1$ to $16: 1(v / w))$, extraction time (15 to $120 \mathrm{~min}$ ), agitation speed (50 to $300 \mathrm{rpm})$ and extraction temperature $\left(25\right.$ to $\left.50^{\circ} \mathrm{C}\right)$ were also optimized.

After optimizing extraction conditions, the percentage efficiency of xylanase recovery was studied under unoptimized and optimized extraction conditions. The percentage efficiency of xylanase recovery was calculated as follows:

$$
\% \text { Xylanase recovery }=\frac{\text { Xylanase activity extracted }}{\text { Total xylanase activity in fermented substrate }}
$$

Effect of optimized upstream and downstream conditions on total xylanase yield

At the end of detailed upstream and downstream process optimization, additional set of experiment for total xylanase productivity was carried out under the optimized conditions and obtained results were compared with earlier-reported xylanase-producing Aspergillus strains.

\section{Results and discussion}

Selection of agro-residues for xylanase production

Due to its high cost, pure xylan is not affordable for large-scale production of xylanase. Utilization of agricultural residues for enzyme production may serve a dual purpose: on one side, it provides a valuable metabolite, and on the other side, it helps in solving environmental solid waste disposal problem. Therefore, various lowcost agricultural residues were explored for the xylanase production. After 6 days of cultivation, among the tested agro-residues, sorghum straw supported maximum xylanase activity $(615.5 \pm 19.21 \mathrm{U} / \mathrm{g})$ followed by wheat straw, sugarcane bagasse and rice straw (Table 1). Till date studies on xylanase production using sorghum straw as a substrate under SSF are scarce. It is believed that the substrate from graminaceous plants containing arabinoxylans supports high xylanase production [17]. The high xylanase titre when sorghum straw was used may be attributed to the nature of hemicelluloses, presence of some activators, surface pore size and favourable degradability of the carbon source. Thus, sorghum straw was used as a substrate throughout the optimization of upstream and downstream process parameters for xylanase production by $A$. tubingensis FDHN1 under SSF. Previously, use of sorghum straw has been reported as a potent inducer for xylanase production from Thermomyces lanuginosus under SSF by Sonia et al. [18]. However, xylanase production under SSF using wheat bran has also been reported by Aspergillus niger [11], A. niger and Aspergillus niveus [19].

In the present study, a variation in xylanase production was observed with the change in sorghum straw concentration from 3.0 to $15 \mathrm{~g}$. Maximum xylanase production $(1,329 \pm 29 \mathrm{U} / \mathrm{g})$ with very poor cellulase activity $(0.42 \pm 0.02 \mathrm{U} / \mathrm{g})$ was obtained using $9 \mathrm{~g}$ sorghum straw under SSF (Figure S1 in Additional file 1).

\section{Evaluation of upstream bioprocess parameters for xylanase production}

Effect of incubation period and substrate to moisture ratio

The fermentation time for the maximum enzyme production is dependent upon the organism type and cultural/environmental conditions. Xylanase production at different time intervals during SSF showed that it was initiated from the second day and reached the maximum $(1,217 \pm 14 \mathrm{U} / \mathrm{g})$ on the fifth day with specific xylanase activity of $53.54 \pm 1.88 \mathrm{U} / \mathrm{mg}$ (Figure 1 ). Xylanase activity was found to decrease sharply with prolonged incubation. This result suggested that the fermentation endpoint should be controlled carefully because non-specific proteases secreted by the fungus may degrade the synthesized xylanase. The decrease in xylanase production may also be due to the accumulation of the end products during fermentation. SSF has also been carried out by Pandya and Gupte [20] for 10 days to produce xylanase from $A$.

Table 1 Effect of various agro-residues on xylanase production from $A$. tubingensis FDHN1 under SSF

\begin{tabular}{lcccc}
\hline Agricultural residue $^{\mathbf{a}}$ & Xylanase activity (U/g) & Protein $\mathbf{( m g / g )}$ & Specific activity (U/mg) & Cellulase activity (U/g) \\
\hline Caster waste & $284 \pm 10.00$ & $31.40 \pm 1.24$ & $9.04 \pm 0.36$ & $1.26 \pm 0.03$ \\
Sugarcane bagasse & $459.7 \pm 8.21$ & $33.75 \pm 1.0$ & $13.62 \pm 0.62$ & $1.04 \pm 0.02$ \\
Wood chips & $78.1 \pm 3.47$ & $21.22 \pm 0.69$ & $3.68 \pm 0.15$ & $2.81 \pm 0.08$ \\
Wheat straw & $495.5 \pm 6.46$ & $37.5 \pm 1.65$ & $13.21 \pm 0.31$ & $1.5 \pm 0.04$ \\
Maize straw & $344.1 \pm 14.26$ & $32.19 \pm 1.11$ & $10.68 \pm 0.48$ & $0.73 \pm 0.01$ \\
Rice straw & $453.2 \pm 12.36$ & $33.85 \pm 0.56$ & $13.38 \pm 0.71$ & $2.0 \pm 0.1$ \\
Sorghum straw & $615.5 \pm 19.21$ & $32.87 \pm 1.41$ & $18.72 \pm 0.91$ & $0.6 \pm 0.02$ \\
Groundnut shell & $252.9 \pm 8.29$ & $26.84 \pm 0.9$ & $9.42 \pm 0.33$ & $0.71 \pm 0.06$ \\
Barley straw & $185 \pm 4.34$ & $35.23 \pm 1.21$ & $5.25 \pm 0.21$ & $1.05 \pm 0.04$ \\
\hline SSF was can
\end{tabular}

${ }^{\text {a }} \mathrm{SSF}$ was carried out using $5 \mathrm{~g}$ of substrate moistened with $5 \mathrm{~mL}$ mineral salt medium pH 5.0 at $35^{\circ} \mathrm{C}$ for 6 days. The data presented are the mean values of three replicates with standard deviations. 


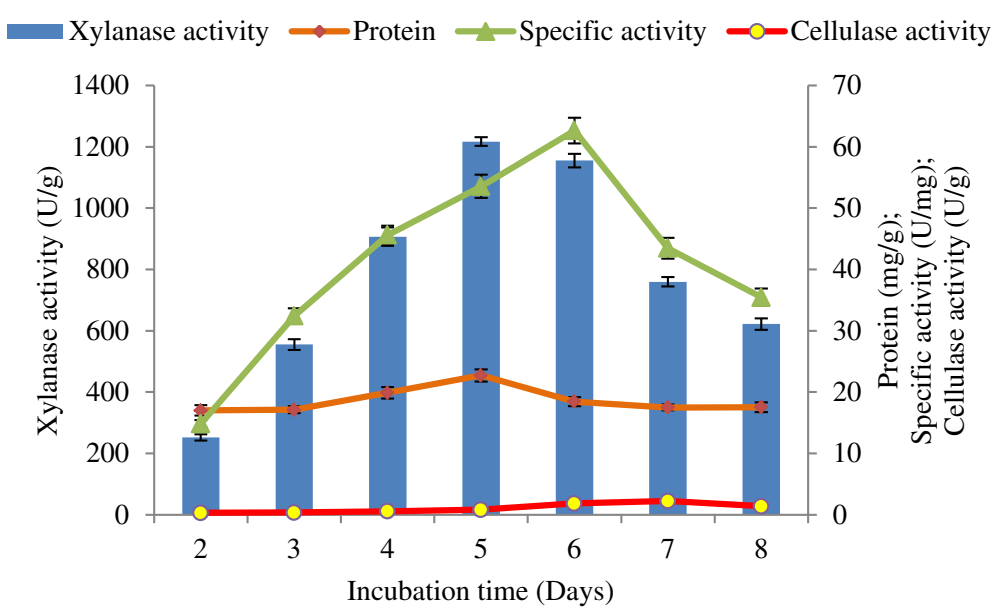

Figure 1 Effect of incubation time on the xylanase production. SSF was carried out using $9 \mathrm{~g}$ sorghum straw for respective days ( 2 to 8 days) at $35^{\circ} \mathrm{C}$, and samples were analysed at a regular interval of $24 \mathrm{~h}$.

tubingensis JP-1 using wheat straw. They have noticed optimum xylanase yield on the eighth day of incubation. However, an increase in the xylanase production was observed by Goyal et al. [21] up to 17 days of fermentation using various agro-residues under SSF by Trichoderma viride. The above results indicated that the fermentation time for enzyme production under SSF depends on the growth rate of the microorganism and its pattern for enzyme production. The strain $A$. tubingensis FDHN1 used in the present study showed relatively high xylanase production within a short incubation period which could be attractive for large-scale xylanase production.

Apart from incubation time, moisture content plays a major role during SSF in the regulation of microbial metabolism known as water activity [22]. In the present investigation, influence of moisture content was studied at different solid/liquid ratios of 1:1 to $1: 7(w / v)$. The highest xylanase production $(1,659 \pm 17 \mathrm{U} / \mathrm{g})$ and specific xylanase activity $(81.60 \pm 1.18 \mathrm{U} / \mathrm{mg})$ were obtained at 1:5 $(w / v)$ moisture ratio after 5 days of incubation, while maximum cellulase production $(2.03 \pm 0.11 \mathrm{U} / \mathrm{g})$ was achieved at 1:6 $(w / v)$ moisture ratio. In some fungi, high xylanase production has been shown to be firmly associated with cellulase production [23], but $A$. tubingensis FDHN1 did not produce much cellulase at different time intervals and moisture ratios. At 1:6 and 1:7 $(w / v)$ moisture ratios, the xylanase production decreased to $1,463 \pm 6$ and 1,397 $\pm 6 \mathrm{U} / \mathrm{g}$, respectively (Table 2 ). The obtained results indicated that the deviations from the optimum level moisture content lead to reduced xylanase production. In SSF, moisture content is an important factor that determines the overall success of a process by altering the physical properties of the solid substratum. The lower xylanase production at higher moisture levels could attribute to the decrease in porosity, alteration in particle structure or lower oxygen transfer, whereas the lower moisture content leads to a reduction in the diffusion of the nutrients in the substrate, lower degree of swelling and higher water tension [24]. Previously, optimum moisture level of 1:5 ( $w / v)$ has been shown for the xylanase production after 10 days under SSF by Pandya and Gupte [20].

\section{Effect of $\mathrm{pH}$ and temperature}

The enzyme production by microbial strains strongly depends on the initial $\mathrm{pH}$ of the medium as it influences many enzymatic processes and transport of various components across the cell membrane [25]. In the present study, xylanase production was noticed in the wide range of $\mathrm{pH} 3.0$ to 9.0 (Table 2) and high xylanase production $(2,012 \pm 18 \mathrm{U} / \mathrm{g})$ with poor cellulase activity $(1.64 \pm 0.12 \mathrm{U} / \mathrm{g})$ was achieved at $\mathrm{pH}$ 6.0. However, substantial xylanase production was also observed at $\mathrm{pH} 5.0$ (1,606 $\pm 7 \mathrm{U} / \mathrm{g}), 7.0(1,924 \pm 15 \mathrm{U} / \mathrm{g}), 8.0(1,745 \pm 13 \mathrm{U} / \mathrm{g})$ and $9.0(1,565 \pm 19 \mathrm{U} / \mathrm{g})$. These results indicated that $A$. tubingensis FDHN1 was not only grown successfully in acidic and alkaline $\mathrm{pH}$ but also generated considerable xylanase titre. However, xylanase production by $A$. tubingensis JP-1 has been observed to decrease drastically under acidic and alkaline $\mathrm{pH}$ ranges [20]. Liao et al. [26] have reported higher xylanase production by Penicillium oxalicum GZ-2 at pH 5.0. The highest xylanase has been produced by $A$. niveus RS2 at a neutral to alkaline $\mathrm{pH}$ than at an acidic and high alkaline $\mathrm{pH}$ [27].

In the present study, optimum xylanase production $(1,998 \pm 12 \mathrm{U} / \mathrm{g})$ and specific activity $(71.35 \pm 2.97 \mathrm{U} / \mathrm{mg})$ were noticed at $40^{\circ} \mathrm{C}$. At the same temperature, cellulase activity was increased to $2.87 \pm 0.16 \mathrm{U} / \mathrm{g}$. The xylanase and cellulase activity data suggested that the temperature is an important parameter which regulates the enzyme production by $A$. tubingensis FDHN1. At higher temperatures, xylanase production declined sharply and it was $50 \%$ at $55^{\circ} \mathrm{C}$ (Table 2). Although, the physiological changes 
Table 2 Evaluation of physiological parameters for xylanase production from $A$. tubingensis FDHN1 under SSF

\begin{tabular}{|c|c|c|c|c|c|c|c|}
\hline \multirow[t]{2}{*}{ Variable } & \multicolumn{7}{|c|}{ Substrate/moisture ratio ${ }^{a}(w / v)$} \\
\hline & 1:1 & $1: 2$ & $1: 3$ & $1: 4$ & $1: 5$ & $1: 6$ & $1: 7$ \\
\hline Xylanase activity (U/g) & $1,064 \pm 12$ & $1,257 \pm 8$ & $1,356 \pm 9$ & $1,430 \pm 13$ & $1,659 \pm 17$ & $1,463 \pm 6$ & $1,397 \pm 6$ \\
\hline Protein (mg/g) & $16.34 \pm 0.63$ & $18.20 \pm 0.46$ & $16.69 \pm 0.79$ & $20.04 \pm 0.87$ & $20.33 \pm 0.29$ & $19.53 \pm 0.67$ & $18.29 \pm 0.75$ \\
\hline Specific activity (U/mg) & $65.11 \pm 2.47$ & $69.06 \pm 3.21$ & $81.24 \pm 3.66$ & $71.35 \pm 2.59$ & $81.60 \pm 1.18$ & $74.91 \pm 3.34$ & $76.38 \pm 3.09$ \\
\hline Cellulase activity (U/g) & $0.21 \pm 0.04$ & $0.53 \pm 0.02$ & $0.64 \pm 0.01$ & $1.53 \pm 0.06$ & $2.03 \pm 0.11$ & $2.59 \pm 0.10$ & $2.07 \pm 0.15$ \\
\hline \multirow[t]{2}{*}{ Variable } & \multicolumn{7}{|c|}{$\mathrm{pH}^{\mathrm{b}}$} \\
\hline & 3 & 4 & 5 & 6 & 7 & 8 & 9 \\
\hline Xylanase activity (U/g) & $978 \pm 5$ & $1,331 \pm 12$ & $1,606 \pm 7$ & $2,012 \pm 18$ & $1,924 \pm 15$ & $1,745 \pm 13$ & $1,565 \pm 19$ \\
\hline Protein (mg/g) & $16.87 \pm 0.57$ & $21.97 \pm 0.92$ & $25.01 \pm 1.03$ & $24.44 \pm 0.87$ & $26.27 \pm 1.00$ & $26.24 \pm 0.81$ & $24.03 \pm 0.78$ \\
\hline Specific activity (U/mg) & $57.97 \pm 2.88$ & $60.58 \pm 1.24$ & $64.21 \pm 2.55$ & $82.32 \pm 2.31$ & $73.25 \pm 3.09$ & $66.50 \pm 2.99$ & $65.12 \pm 3.18$ \\
\hline Cellulase activity (U/g) & ND & ND & $0.78 \pm 0.08$ & $1.64 \pm 0.12$ & $2.33 \pm 0.07$ & $3.17 \pm 0.13$ & $2.56 \pm 0.13$ \\
\hline \multirow[t]{2}{*}{ Variable } & \multicolumn{7}{|c|}{ Temperature $^{c}\left({ }^{\circ} \mathrm{C}\right)$} \\
\hline & 25 & 30 & 35 & 40 & 45 & 50 & 55 \\
\hline Xylanase activity (U/g) & $1,452 \pm 19$ & $1,808 \pm 15$ & $1,860 \pm 15$ & $1,998 \pm 12$ & $1,623 \pm 10$ & $1,331 \pm 15$ & $1,056 \pm 10$ \\
\hline Protein (mg/g) & $25.29 \pm 0.98$ & $26.66 \pm 1.21$ & $27.93 \pm 0.77$ & $28.00 \pm 0.61$ & $24.33 \pm 1.03$ & $24.34 \pm 1.14$ & $23.33 \pm 0.62$ \\
\hline Specific activity (U/mg) & $57.41 \pm 2.43$ & $67.81 \pm 2.08$ & $66.59 \pm 1.26$ & $71.35 \pm 2.97$ & $66.70 \pm 3.04$ & $54.68 \pm 1.33$ & $45.26 \pm 1.97$ \\
\hline Cellulase activity (U/g) & ND & $0.64 \pm 0.10$ & $2.15 \pm 0.08$ & $2.87 \pm 0.16$ & $2.06 \pm 0.13$ & $1.31 \pm 0.04$ & $0.80 \pm 0.06$ \\
\hline
\end{tabular}

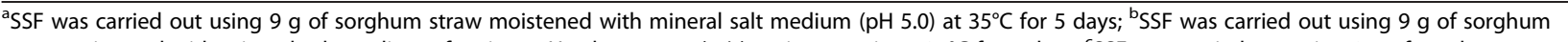
straw moistened with mineral salt medium of various $\mathrm{pH}$ values at $1: 5(\mathrm{w} / \mathrm{v})$ moisture ratio at $35^{\circ} \mathrm{C}$ for 5 days; ${ }^{\mathrm{C}} \mathrm{SSF}$ was carried out using $9 \mathrm{~g}$ of sorghum straw

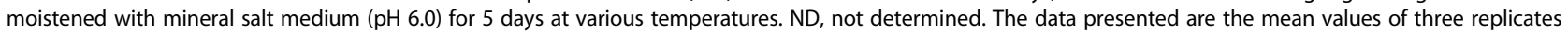
with the standard deviations.

induced by high temperature during enzyme production are not completely understood. It has been suggested that at higher temperatures, microorganisms may synthesize only a reduced number of proteins essential for growth and other physiological processes [8]. It has been shown in a previous study that $A$. tubingensis $\mathrm{JP}-1$ was unable to produce a considerable xylanase yield above $30^{\circ} \mathrm{C}$ [20]. The results of incubation time, $\mathrm{pH}$ and temperature study indicate that $A$. tubingensis FDHN1 has far better xylanase production ability across the $\mathrm{pH}$ and temperature range within short fermentation time as compared to earlier reported A. tubingensis JP-1.

\section{Influence of carbon and organic/inorganic nitrogen sources} Carbon sources are very important for the growth and metabolic processes of microorganisms. The xylanase and cellulase production in the presence of different carbon sources are shown in Table 3. Addition of $0.5 \%$ xylose in the fermentation medium enhanced the xylanase production $(2,267 \pm 12 \mathrm{U} / \mathrm{g})$ with low cellulase activity $(1.85 \pm 0.09 \mathrm{U} / \mathrm{g})$. However, fructose, mannitol, lactose, maltose, glucose and sucrose were affected adversely to the xylanase production. The level of cellulase production was reached to $3.68 \pm 0.07 \mathrm{U} / \mathrm{g}$ in the presence of glucose, but the xylanase production was affected negatively. Xylanase and cellulase are known to be inducible in fungi and are affected by the nature of the substrate used in the study [23]. To enhance the xylanase production, xylose was selected as the best carbon source and its concentration in medium was varied from 0.1 to $1.1 \%$. The results indicated that $0.3 \%$ xylose gave high xylanase yield $(2,349 \pm 17 \mathrm{U} / \mathrm{g})$ (Figure S2 in Additional file 1). It has been suggested that xylose is not only a carbon source but also an effective inducer for the xylanase production [28]. In the present study, xylose concentration above $0.3 \%$ reduced the xylanase production gradually. Such carbon source concentration-dependent enzyme production regulation has been noticed in different xylanase-producing microbial strains by various research groups $[29,30]$.

Formation of extracellular enzymes is greatly influenced by the availability of nitrogen source as it is the ultimate precursor of protein synthesis. Furthermore, nitrogen source can significantly affect the $\mathrm{pH}$ of the medium during the course of fermentation, and hence, the enzyme activity and stability may get influenced. Among the different organic nitrogen sources tested, gelatine was found to support the maximum xylanase production $(2,453 \pm 11$ $\mathrm{U} / \mathrm{g})$. In this study, all the tested nitrogen sources enhanced the xylanase production as compared to control (Table 4). During the study with different inorganic nitrogen sources, sodium nitrate induced the xylanase production $(2,589 \pm 22 \mathrm{U} / \mathrm{g})$. The xylanase production from Trichoderma viride in the presence of $\mathrm{NaNO}_{3}$ as an inorganic nitrogen source has also been reported by Goyal et al. [21]. In the present study, combination of gelatine and sodium nitrate further improved the 
Table 3 Effect of carbon sources on xylanase production from A. tubingensis FDHN1 under SSF

\begin{tabular}{lcccc}
\hline Carbon source $^{\mathbf{a}}$ & $\begin{array}{c}\text { Xylanase activity } \\
\mathbf{U} / \mathbf{g}\end{array}$ & Protein & Specific activity & \multicolumn{2}{c}{ Cellulase activity } \\
& $\mathbf{m g} / \mathbf{g}$ & $\mathbf{U} / \mathbf{m g}$ & $\mathbf{U} \mathbf{g}$ \\
\hline Control $^{\mathbf{b}}$ & $1,875 \pm 13$ & $26.84 \pm 0.33$ & $69.85 \pm 2.86$ & $2.31 \pm 0.11$ \\
Glucose & $1,601 \pm 14$ & $28.06 \pm 0.79$ & $57.05 \pm 1.93$ & $3.68 \pm 0.07$ \\
Fructose & $1,871 \pm 11$ & $27.70 \pm 1.13$ & $67.54 \pm 2.37$ & $2.06 \pm 0.14$ \\
Sucrose & $1,644 \pm 10$ & $25.51 \pm 0.94$ & $64.44 \pm 2.11$ & $2.57 \pm 0.06$ \\
Xylose & $2,267 \pm 12$ & $28.61 \pm 1.22$ & $79.23 \pm 3.40$ & $1.85 \pm 0.09$ \\
Lactose & $1,267 \pm 19$ & $24.36 \pm 1.05$ & $52.01 \pm 1.23$ & $1.63 \pm 0.13$ \\
Maltose & $1,463 \pm 12$ & $23.87 \pm 0.98$ & $61.29 \pm 2.74$ & $3.11 \pm 0.13$ \\
Mannitol & $1,206 \pm 19$ & $20.96 \pm 0.87$ & $57.53 \pm 2.66$ & $2.49 \pm 0.08$ \\
\hline
\end{tabular}

${ }^{\mathrm{a}} \mathrm{SSF}$ was carried using $9 \mathrm{~g}$ sorghum straw under optimized physiological conditions (at 5-day incubation, 1:5 ( $w / v$ ) substrate/moisture ratio, $\mathrm{pH} 6.0$ and $40^{\circ} \mathrm{C}$ ); ${ }^{b}$ the control medium used was devoid of any carbon source. The data presented are the mean values of three replicates with the standard deviations.

xylanase $(2,697 \pm 18 \mathrm{U} / \mathrm{g})$ and cellulase $(3.86 \pm 0.06 \mathrm{U} / \mathrm{g})$ yield.

\section{Influence of metal additives and modulators}

The choice of an appropriate additive is of great importance for the successful production of xylanase. Among tested metal compounds, $\mathrm{MgCl}_{2}$ exhibited the clear stimulation in xylanase yield $(2,446 \pm 27 \mathrm{U} / \mathrm{g})$ followed by $\mathrm{CuCl}_{2}, \mathrm{CaCl}_{2}, \mathrm{MnCl}_{2}$ and $\mathrm{FeCl}_{3}$. However, $\mathrm{HgCl}_{2}$,
$\mathrm{CoCl}_{2}, \mathrm{SnCl}_{2}$ and $\mathrm{NiCl}_{2}$ responded negatively towards xylanase production (Table S1 in Additional file 1). Similarly, addition of various modulators to the culture medium exerts a range of effects on the enzyme secretion. In the presence of Tween-80, the levels of cellulase and xylanase activities were increased to $4.21 \pm 0.13$ and $2,449 \pm 23 \mathrm{U} / \mathrm{g}$, respectively, which could be due to its favourable effect on cell permeability and thus it affects the secretion of certain proteins [31]. In addition,

Table 4 Effect of nitrogen sources on xylanase production from A. tubingensis FDHN1 under SSF

\begin{tabular}{|c|c|c|c|c|}
\hline Nitrogen source ${ }^{a}$ & $\begin{array}{c}\text { Xylanase activity } \\
\text { U/g }\end{array}$ & $\begin{array}{l}\text { Protein } \\
\mathrm{mg} / \mathrm{g}\end{array}$ & $\begin{array}{c}\text { Specific activity } \\
\text { U/mg }\end{array}$ & $\begin{array}{c}\text { Cellulase activity } \\
\mathrm{U} / \mathrm{g}\end{array}$ \\
\hline Control $^{b}$ & $1,986 \pm 13$ & $25.84 \pm 0.56$ & $76.85 \pm 3.45$ & $1.63 \pm 0.08$ \\
\hline \multicolumn{5}{|l|}{ Organic } \\
\hline Peptone & $2,071 \pm 11$ & $25.92 \pm 1.48$ & $79.89 \pm 2.64$ & $3.02 \pm 0.18$ \\
\hline Beef extract & $2,189 \pm 10$ & $24.35 \pm 1.34$ & $89.89 \pm 3.89$ & $2.54 \pm 0.09$ \\
\hline Urea & $2,432 \pm 14$ & $25.1 \pm 0.89$ & $96.89 \pm 1.26$ & $2.81 \pm 0.13$ \\
\hline Yeast extract & $2,401 \pm 11$ & $26.63 \pm 1.08$ & $90.16 \pm 4.15$ & $1.67 \pm 0.11$ \\
\hline Tryptone & $2,004 \pm 12$ & $24.77 \pm 1.07$ & $80.90 \pm 3.86$ & $3.72 \pm 0.16$ \\
\hline Malt extract & $2,348 \pm 15$ & $24.18 \pm 0.96$ & $97.10 \pm 2.41$ & $3.09 \pm 0.16$ \\
\hline Meat extract & $2,262 \pm 14$ & $25.34 \pm 1.21$ & $89.26 \pm 3.02$ & $2.84 \pm 0.06$ \\
\hline Gelatine & $2,453 \pm 11$ & $25.09 \pm 1.14$ & $97.76 \pm 3.37$ & $3.28 \pm 0.12$ \\
\hline Skim milk powder & $2,347 \pm 11$ & $24.69 \pm 0.88$ & $95.05 \pm 3.98$ & $1.52 \pm 0.15$ \\
\hline \multicolumn{5}{|l|}{ Inorganic } \\
\hline$\left(\mathrm{NH}_{4}\right)_{2} \mathrm{HPO}_{4}$ & $2,148 \pm 20$ & $25.61 \pm 1.05$ & $83.87 \pm 2.46$ & $2.44 \pm 0.07$ \\
\hline$\left(\mathrm{NH}_{4}\right)_{2} \mathrm{H}_{2} \mathrm{PO}_{4}$ & $2,367 \pm 14$ & $4.89 \pm 0.46$ & $95.09 \pm 1.84$ & $3.81 \pm 0.14$ \\
\hline$\left(\mathrm{NH}_{4}\right)_{2} \mathrm{SO}_{4}$ & $2,272 \pm 21$ & $23.5 \pm 1.12$ & $96.68 \pm 2.92$ & $3.33 \pm 0.11$ \\
\hline$\left(\mathrm{NH}_{4}\right)_{2} \mathrm{~S}_{2} \mathrm{O}_{8}$ & $2,430 \pm 20$ & $24.31 \pm 0.98$ & $99.95 \pm 3.36$ & $2.16 \pm 0.14$ \\
\hline $\mathrm{NH}_{4} \mathrm{NO}_{3}$ & $2,464 \pm 15$ & $25.17 \pm 1.26$ & $97.89 \pm 2.71$ & $2.62 \pm 0.08$ \\
\hline $\mathrm{NH}_{4} \mathrm{Cl}$ & $2,435 \pm 16$ & $22.96 \pm 1.11$ & $106.05 \pm 1.50$ & $1.38 \pm 0.12$ \\
\hline $\mathrm{NaNO}_{3}$ & $2,589 \pm 22$ & $23.84 \pm 1.03$ & $108.59 \pm 2.08$ & $3.59 \pm 0.17$ \\
\hline Gelatine $+\mathrm{NaNO}_{3}$ & $2,697 \pm 18$ & $25.98 \pm 1.02$ & $103.50 \pm 3.57$ & $3.86 \pm 0.06$ \\
\hline
\end{tabular}

${ }^{a} \mathrm{SSF}$ was carried using $9 \mathrm{~g}$ sorghum straw under optimized physiological conditions (at 5-day incubation, 1:5 ( $\mathrm{w} / \mathrm{v}$ ) substrate/moisture ratio, $\mathrm{pH} 6.0$ and $40^{\circ} \mathrm{C}$ ); ${ }^{b}$ the control medium used was devoid of any organic or inorganic nitrogen source. The data presented are the mean values of three replicates with the standard deviations. 
Tween-40, glycine and glycerol also showed its stimulatory effects on the xylanase synthesis.

\section{Enzymatic properties of crude xylanase Effect of $\mathrm{pH}$ on the activity and stability}

Xylanase activity was studied in the wide range of $\mathrm{pH}$ 3.0 to 10 using different buffers to find out the best $\mathrm{pH}$ for the enzyme. The crude enzyme extract exhibited the maximum xylanase activity at $\mathrm{pH} 5.0$ and retained more than $80 \%$ of its activity between $\mathrm{pH}$ 3. to 7.0 (Figure $2 \mathrm{~A}$ ). The xylanase activity was found to be affected slightly by variation in the $\mathrm{pH}$ outside its optimum $\mathrm{pH}$. However, it decreased drastically at pH 9.0 and 10. Betini et al. [19] have measured xylanase activity at different $\mathrm{pH} 4.0$ to 8.0. They have observed the optimum $\mathrm{pH} 5.0$ to 5.5 for A. niveus, pH 5.5 to 6.0 for $A$. niger and pH 5.0 for $A s$ pergillus ochraceus xylanase activities from crude enzyme extracts. During $\mathrm{pH}$ stability studies, A. tubingensis
FDHN1 xylanase showed high stability towards a broad range of pH 3.0 to 9.0 (Figure $2 \mathrm{~B}$ ). The enzyme retained its $50 \%$ activity $\left(t_{50}\right)$ after 9,15 and $15 \mathrm{~h}$ of incubation in the acidic range $\mathrm{pH} 3.0,4.0$ and 5.0, respectively. At $\mathrm{pH}$ 6.0 and 7.0, xylanase showed good stability even after 24 h. However, at pH 7.0, 8.0 and 9.0, the half xylanase activities were noticed after 15, 9 and $6 \mathrm{~h}$, respectively. These results indicate that xylanase from $A$. tubingensis FDHN1 is highly active and stable within a broad $\mathrm{pH}$ range as compared to the reported xylanases from several other Aspergillus sp. [19,32].

\section{Effect of temperature on the activity and stability}

The effect of different temperatures on xylanase activity is shown in Figure 3A. The highest xylanase activity was observed at $50^{\circ} \mathrm{C}$. In the present study, approximately 30 and $70 \%$ reduction in the xylanase activity were observed at 55 and $60^{\circ} \mathrm{C}$, respectively. Enzyme activity reduced
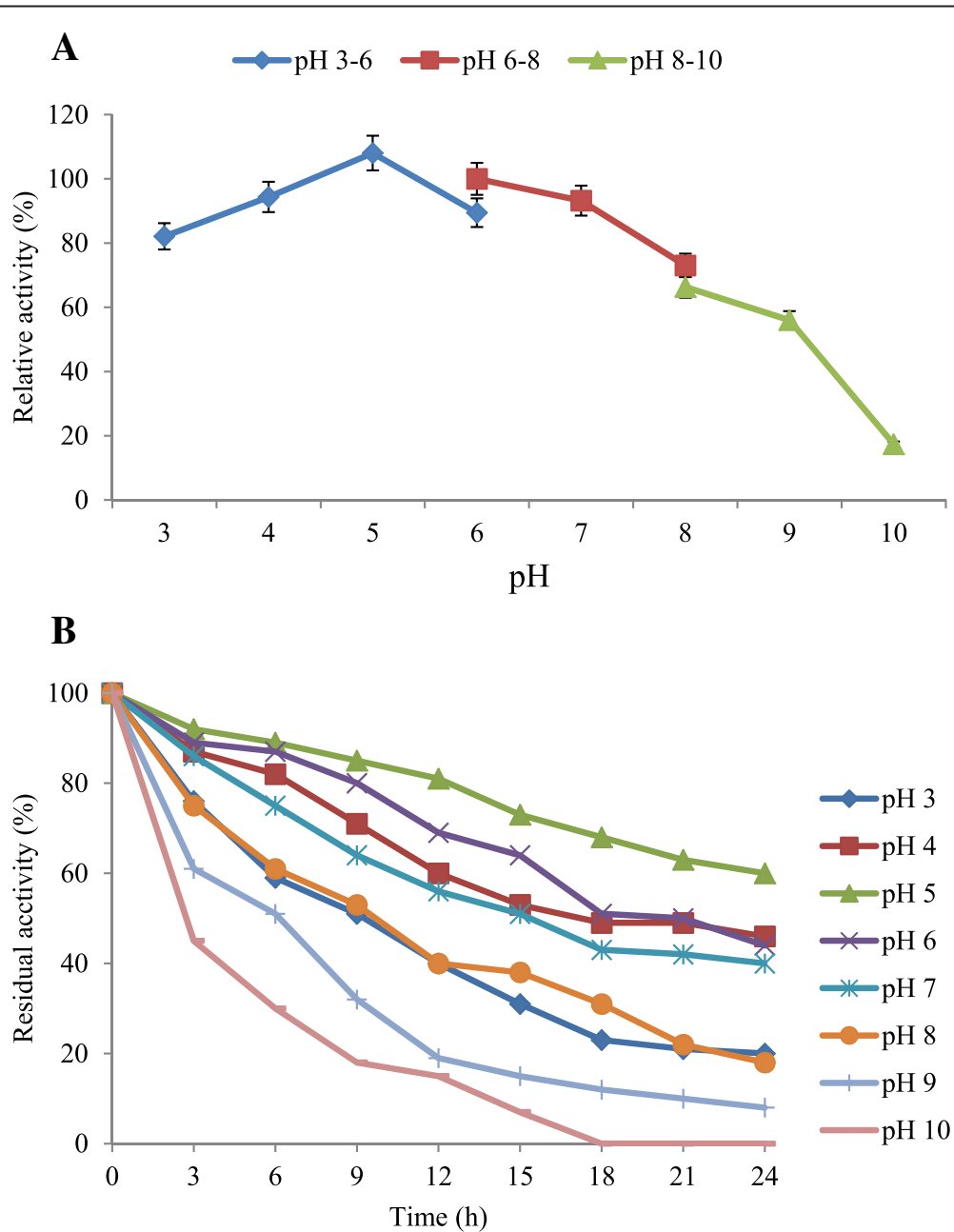

Figure 2 Optimal pH (A) and pH stability (B) of the xylanase from A. tubingensis FDHN1. The influence of pH on xylanase activity was determined using $0.05 \mathrm{M}$ sodium citrate ( $\mathrm{pH} 3.0$ to 6.0 ), sodium phosphate ( $\mathrm{pH} 6.0$ to 8.0 ) and glycine- $\mathrm{NaOH}$ (pH 8.0 to 10) buffers. The pH stability was studied at a regular interval of 3 up to $24 \mathrm{~h}$. 

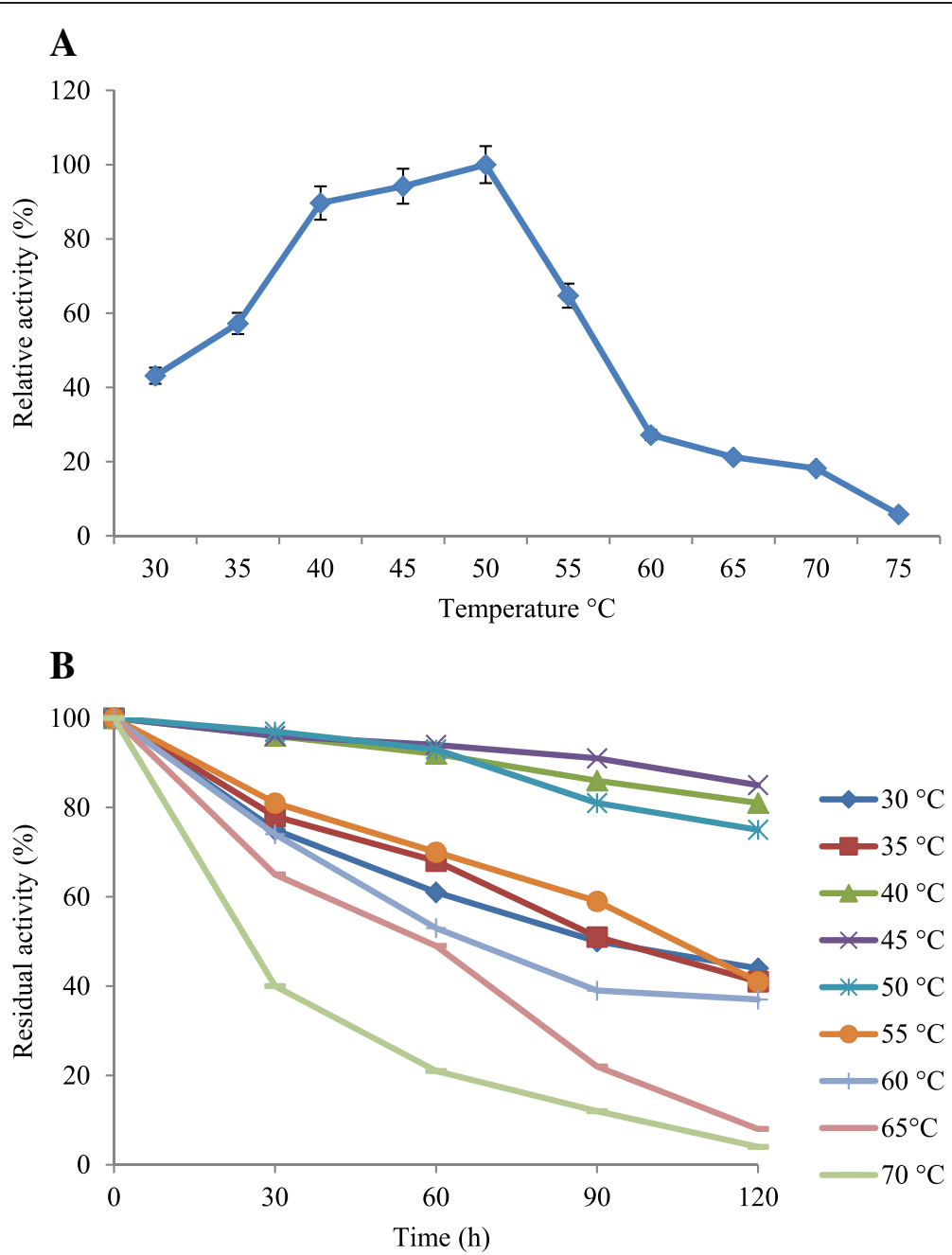

Figure 3 Optimal temperature (A) and thermal stability (B) of the xylanase from A. tubingensis FDHN1. Xylanase activity was measured at different temperatures to determine its optimal range. For the determination of thermal stability, the residual activity of the xylanase was measured after 30,60, 90 and 120 min pre-incubation at different temperatures.

drastically with further increase in the temperature. The present xylanase exhibited more than $70 \%$ thermal stability at temperature range of 35 to $55^{\circ} \mathrm{C}$ after $60 \mathrm{~min}$ (Figure 3B), and it showed maximum stability at $45^{\circ} \mathrm{C}$ by retaining $85 \%$ residual activity after $120 \mathrm{~min}$. The xylanase $t_{50}$ was observed after 60 and $90 \mathrm{~min}$ at 30 and $35^{\circ} \mathrm{C}$, respectively. At 40,45 and $50^{\circ} \mathrm{C}, t_{50}$ was noticed after 195 , 180 and $155 \mathrm{~min}$, respectively. The xylanase retained 51, 53 and $50 \%$ activity even at temperature $55^{\circ} \mathrm{C}(90 \mathrm{~min})$, $60^{\circ} \mathrm{C}(60 \mathrm{~min})$ and $65^{\circ} \mathrm{C}(50 \mathrm{~min})$, respectively. These results show that the activity and stability of xylanase at various temperatures were high as compared to the existing Aspergillus sp. xylanases [19,32,33].

\section{Effect of organic solvents on the activity}

Published studies of the mechanism of adaptation of enzymes for functioning into the organic solvent are relatively few. In the present study, effects of various organic solvents and its concentration on the xylanase activity were examined (Figure S3 in Additional file 1). The xylanase retained more than $85 \%$ of its initial activity with all the solvents at $10 \%$ concentration except benzene. In the presence of $30 \%$ acetone, butanol and propanol, xylanase retained more than $70 \%$ of the initial activity after $30 \mathrm{~min}$. This result is interesting with an aim of using the present xylanase in an application requiring the incubation of the enzyme with organic solvents. The mechanism of organic solvent tolerance has been investigated by Ogino et al. [34] in a Pseudomonas aeruginosa PST-01 protease by site-directed and random mutagenesis. They have reported that the disulfide bonds and amino acid residues located on the surface of the molecule play an important role in the organic solvent stability of the enzymes. Gupta et al. [35] have proposed that the presence of hydrophobic clusters on the protein surface and disulfide bonds was responsible for 
the solvent-stable nature of enzymes. Previously, Ines et al. [36] have studied the effect of various solvents up to $40 \%$ concentration on the activity of xylanase produced by Talaromyces thermophilus and observed maximum activity in the presence of $5 \%$ ethanol. However, reduced xylanase activity has been observed in the presence of methanol when its concentration was increased from 20 to $40 \%$.

\section{Native PAGE and xylan zymography}

The crude enzyme from $A$. tubingensis FDHN1 was analysed by native PAGE and zymography. Figure 4 shows the presence of three clear zones upon xylan zymography, suggesting the presence of at least three xylanases. The approximate molecular weight of three xylanases, namely, Xyl-D1, Xyl-D2 and Xyl-D3 was found to be approximately 94, 30 and $18.60 \mathrm{kDa}$, respectively. This study for the first time highlights multiplicity of the xylanase from $A$. tubingensis. It is believed that the protein modification (e.g. post-translational cleavage) such as glycosylation, proteolysis or both could be responsible for the genesis of multiple enzymes [37]. Apart from posttranslational modifications, multiplicity might also be due to the differential mRNA processing, post-secretional modification and the presence of different alleles of the same gene [3]. In 2010, two thermostable xylanases with a molecular weight of 25.2 and $30 \mathrm{kDa}$ were identified by Sharma et al. from Malbranchea flava which were active under the alkaline conditions [38].

Thus, cellulase-poor xylanase from A. tubingensis FDHN1 seems a novel enzyme, being active and stable at broad $\mathrm{pH}$ and temperature ranges and in the presence of organic solvents. The multiplicity is also an interesting feature of this xylanase. Due to such desirable properties of xylanase, the present study was elaborated to achieve its better recovery from fermented sorghum straw by optimizing downstream process parameters.

\section{Evaluation of downstream process parameters for maximum xylanase recovery}

\section{Selection of an appropriate extraction solvent}

Recovery of the enzyme from solid support is another important aspect of SSF. An ideal solvent extracts the enzyme selectively and completely in minimum contact time. During initial solvent screening experiments, $0.05 \mathrm{M}$ sodium citrate buffer ( $\mathrm{pH}$ 6.5) was found suitable for efficient xylanase recovery $(3,573 \pm 22 \mathrm{U} / \mathrm{g})$ with cellulase activity of $4.02 \pm 0.08 \mathrm{U} / \mathrm{g}$ from the fermented sorghum straw. Extractions with all other solvents gave lower enzyme recoveries (Table 5). Interestingly, in this study, the xylanase was highly active and stable within the acidic range of $\mathrm{pH}$ and its optimum recovery was also found in the presence of an acidic extractant. This could be due to the fact that the use of suitable buffer solutions as a solvent helps in maintaining the $\mathrm{pH}$-dependent enzyme stability. Earlier, distilled water and sodium citrate buffer $50 \mathrm{mM}, \mathrm{pH} 6.5$ were used by Pal and Khanum [11] and Sonia et al. [18] as a solvent for the effective recovery of xylanase from cultivated biomass, respectively. FernendezLahore et al. [39] have pointed that the hydrophobic or hydrophilic nature of fungal mycelia, ionic bonds, hydrogen bonds and van der Waal forces determines the efficiency of extractant for enzyme recovery.

\section{Effect of extractant volume and extraction time}

In this study, volumes of extractant and extraction time were optimized to improve the xylanase recovery. An extractant/solid ratio was kept in the range of 4:1 to $16: 1$ $(v / w)$ while extraction time was varied from 15 to

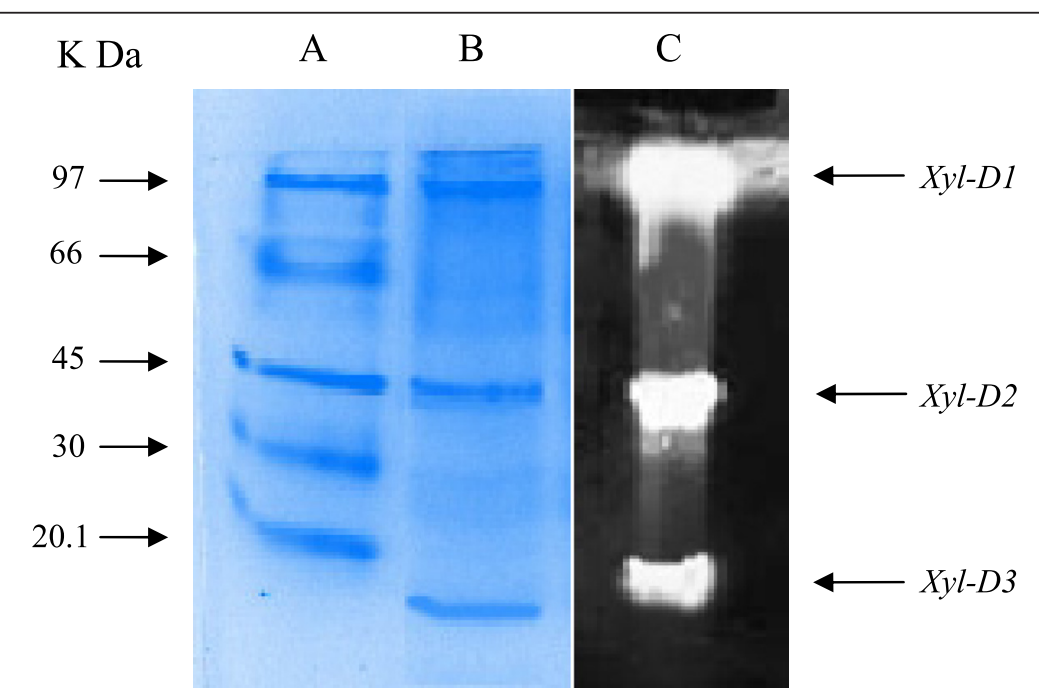

Figure 4 Native PAGE and zymogram analysis of crude enzyme extract from A. tubingensis FDHN1. (A) Molecular weight marker, (B) crude enzyme extract, and (C) xylan zymography. 
Table 5 Effect of various extraction solvents on xylanase recovery from the fermented sorghum straw

\begin{tabular}{lcccc}
\hline Name of extractant $^{\mathbf{a}}$ & Xylanase activity (U/g) & Protein (mg/g) & Specific activity (U/mg) & Cellulase activity (U/g) \\
\hline Citrate buffer (0.05 M, pH 5.0) & $2,591 \pm 50$ & $24.86 \pm 0.99$ & $104.22 \pm 3.55$ & $3.26 \pm 0.11$ \\
Na-citrate buffer (0.05 M, pH 6.5) & $3,573 \pm 22$ & $27.96 \pm 1.08$ & $127.79 \pm 2.13$ & $4.02 \pm 0.08$ \\
Double-distilled water (pH 7.0) & $2,675 \pm 26$ & $26.88 \pm 1.19$ & $99.51 \pm 4.67$ & $3.83 \pm 0.05$ \\
Phosphate buffer (0.05 M, pH 7.5) & $3,256 \pm 23$ & $25.79 \pm 0.79$ & $126.25 \pm 4.06$ & $3.54 \pm 0.14$ \\
Tris buffer (0.05 M, pH 8.0) & $2,859 \pm 13$ & $23.96 \pm 0.96$ & $119.32 \pm 3.24$ & $4.87 \pm 0.17$ \\
Tween-80 (0.2\% V/V) & $3,166 \pm 10$ & $25.47 \pm 0.67$ & $124.30 \pm 3.00$ & $3.09 \pm 0.06$ \\
$\mathrm{NaCl}(1.0 \% \mathrm{~W} / \mathrm{V})$ & $2,416 \pm 18$ & $26.88 \pm 1.07$ & $91.93 \pm 2.67$ & $4.00 \pm 0.13$ \\
\hline
\end{tabular}

${ }^{a}$ SSF was carried using $9 \mathrm{~g}$ sorghum straw under optimized physiological (at 5-day incubation, 1:5 $(w / v)$ substrate/moisture ratio, pH 6.0 and $40^{\circ} \mathrm{C}$ ) and nutritional conditions (xylose $0.3 \%$, gelatine and $\mathrm{NaNO}_{3}$ both at $0.05 \mathrm{~g} \mathrm{~N}$ equivalent in $50 \mathrm{~mL}$ medium). For xylanase recovery, the fermented sorghum straw was mixed with the solvents separately at an extractant/solid ratio of 10:1 (v/w) and agitated at $120 \mathrm{rpm}$ for $60 \mathrm{~min}$ at $37^{\circ} \mathrm{C}$. The data presented are the mean values of three replicates with the standard deviations.

120 min. During the study, the best xylanase extraction $(3,769 \pm 22 \mathrm{U} / \mathrm{g})$ was obtained at an extractant/solid ratio of $12: 1(\mathrm{v} / \mathrm{w})$ and the extraction was further improved $(3,951 \pm 17 \mathrm{U} / \mathrm{g})$ for an extraction time of $90 \mathrm{~min}$. Such increase in the xylanase extraction could be due to the maximum solubilization of the enzyme from the fermented sorghum straw (Figure 5A,B). At 12:1 ( $v / w)$ extractant/solid ratio, the cellulase activity was $4.89 \pm 0.14 \mathrm{U} / \mathrm{g}$ which was reached to $5.17 \pm 0.11 \mathrm{U} / \mathrm{g}$ at $90 \mathrm{~min}$ extraction. The improved xylanase recovery under the above optimized conditions is extremely important because concentrated crude extract ease downstream processes mainly the purification step, reducing the time and cost of enzyme recovery. The use of small volumes of solvent for xylanase recovery greatly reduces the energy requirements, equipment size and pollution, but the volumes that are too low leads to unsatisfactory recoveries, since a significant fraction of the xylanase remains in the fermented solid [40]. Previous studies have shown that 10 to $11 \mathrm{~mL} \mathrm{~g}^{-1}$ [11] and $17 \mathrm{~mL} \mathrm{~g}^{-1}$ [41] solvent/substrate ratio effectively recovers maximum xylanase that was produced by Aspergillus niger DFR-5 and Trichoderma longibrachiatum, respectively.

\section{Effect of agitation speed and extraction temperature}

The xylanase extraction was also studied at different agitation speed and temperature values. During the study, $150 \mathrm{rpm}$ was found suitable for the xylanase recovery

\section{A}

B

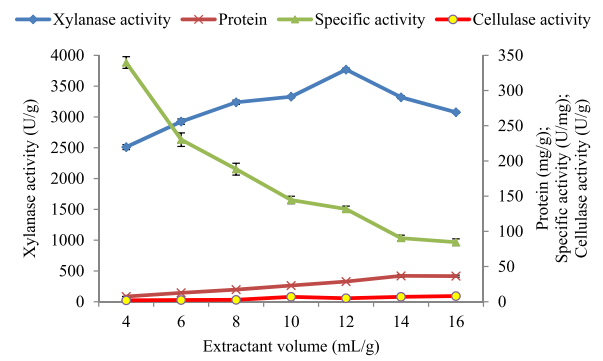

C

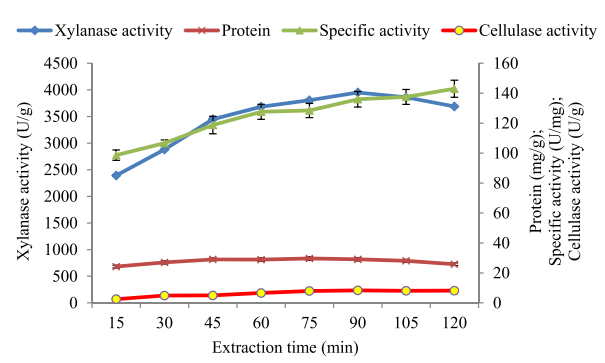

D
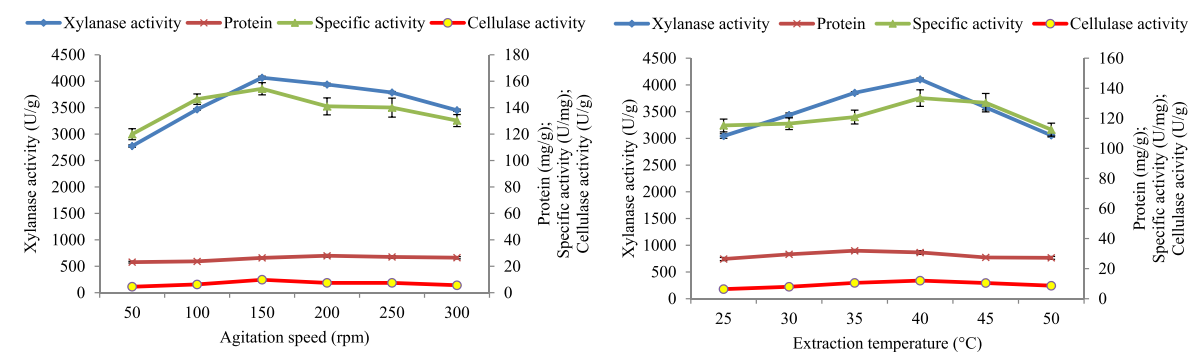

Figure 5 Optimization of xylanase recovery parameters using $0.05 \mathrm{M}$ sodium citrate buffer $\mathrm{pH}$ 6.5. (A) Xylanase recovery was performed using different volumes of extractant at $120 \mathrm{rpm}$ for $60 \mathrm{~min}$ at $37^{\circ} \mathbf{C}$, (B) xylanase recovery was performed at different time intervals using 12:1 $(\mathrm{V} / \mathrm{W})$ extractant/solid ratio at $120 \mathrm{rpm}$ and $\left.37^{\circ} \mathrm{C}, \mathbf{C}\right)$ xylanase recovery was performed at different agitation rates using 12:1 ( $\left.\mathrm{V} / \mathrm{W}\right)$ extractant/solid ratio for $90 \mathrm{~min}$ at $37^{\circ} \mathrm{C}$, and (D) xylanase recovery was performed at different temperatures using 12:1 ( $\mathrm{V} / \mathrm{W}$ ) extractant/solid ratio at $150 \mathrm{rpm}$ for $90 \mathrm{~min}$. 
Table 6 Comparison of $A$. tubingensis FDHN1 with different Aspergillus sp. for xylanase yield and productivity

\begin{tabular}{|c|c|c|c|c|}
\hline Microorganism & Substrate & Xylanase activity (U/g) & Productivity (U/g/day) & Reference \\
\hline Aspergillus tubingensis FDHN1 ${ }^{a}$ & Sorghum straw & 4,105 & 821.00 & This study \\
\hline Aspergillus tubingensis JP-1 & Wheat straw & 6,887 & 859.90 & {$[20]$} \\
\hline Aspergillus niger DFR-5 & Wheat bran & 4,465 & 744.16 & [11] \\
\hline Aspergillus fischeri Fxn 1 & Wheat bran & 1,024 & 341.33 & {$[37]$} \\
\hline Aspergillus fumigates & Wheat bran & 1,055 & 211.00 & [38] \\
\hline Aspergillus fumigates & Sugarcane bagasse/wheat bran (1:1) & 821.0 & 164.20 & {$[38]$} \\
\hline Aspergillus fumigates & Soybean bran & 558.3 & 111.66 & [38] \\
\hline Aspergillus niger & Wheat bran & 1,285 & 257.00 & {$[38]$} \\
\hline Aspergillus niger & Soybean bran & 484.2 & 96.84 & {$[38]$} \\
\hline Aspergillus niger & Sugarcane bagasse/wheat bran (1:1) & 1,050 & 210.00 & {$[38]$} \\
\hline
\end{tabular}

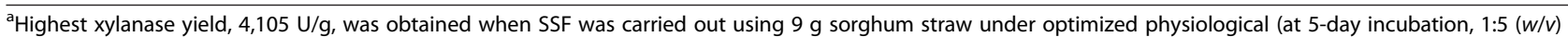
substrate/moisture ratio, $\mathrm{pH} 6.0$ and $40^{\circ} \mathrm{C}$ ) and nutritional conditions (xylose $0.3 \%$, gelatine and $\mathrm{NaNO}_{3}$ both at $0.05 \mathrm{~g} \mathrm{~N}$ equivalent in $50 \mathrm{~mL}$ medium) along with optimized recovery conditions (at an extractant/solid ratio of $12: 1(\mathrm{v} / \mathrm{w}), 150 \mathrm{rpm}, 90 \mathrm{~min}$ and $40^{\circ} \mathrm{C}$ ).

$(4,067 \pm 27 \mathrm{U} / \mathrm{g})$ which was further improved at $40^{\circ} \mathrm{C}$ $(4,105 \pm 22 \mathrm{U} / \mathrm{g})$. The maximum cellulase activity under above optimized conditions was $5.36 \pm 0.17 \mathrm{U} / \mathrm{g}$ (Figure 5C,D). In the present study, xylanase was most stable at $45^{\circ} \mathrm{C}$ and its optimum recovery was observed at $40^{\circ} \mathrm{C}$ suggesting that the enzyme is optimally active at moderately high temperatures. Ghildyal et al. [40] have reported that the prolonged higher rate of agitation causes a loss of enzyme activity. The maximum xylanase extraction has been observed at the highest rate of agitation $(200 \mathrm{rpm})$ with an extraction time of $60 \mathrm{~min}$ at $37^{\circ} \mathrm{C}$ by Pal and Khanum [11]. However, $25^{\circ} \mathrm{C}$ and $200 \mathrm{rpm}$ agitation speed for xylanase recovery has also been reported by Azin et al. [41].

\section{Effect of un-optimized and optimized recovery conditions on xylanase recovery efficiency}

After studying the detailed downstream process parameters, the efficiency of un-optimized and optimized recovery conditions for xylanase recovery were studied at different time intervals. The results indicated that xylanase recovery efficiency was $89.4 \%$ under the optimized conditions after $90 \mathrm{~min}$, whereas it was only $53.3 \%$ under un-optimized conditions after $60 \mathrm{~min}$ (Figure S4 in Additional file 1). After $90 \mathrm{~min}$, the recovery efficiency remained almost constant indicating that the maximum xylanase from the fermented sorghum straw was leached into the extraction solvent during this period. In the present study, the maximum xylanase recovery within a short time indicated the importance of detailed downstream process optimization.

The existing novel strain of $A$. tubingensis FDHN1 has been found to show ability to produce higher cellulasepoor xylanase yield under controlled optimized conditions. The overall productivity of xylanase by $A$. tubingensis FDHN1 has been compared with the existing xylanases produced by different Aspergillus sp. under SSF (Table 6).

\section{Conclusions}

The present study has revealed the potential of a newly isolated $A$. tubingensis FDHN1 to produce xylanase under SSF. The prominent induction of xylanase has been observed in the presence of the least highlighted agricultural residue sorghum straw. The optimization of upstream and downstream process parameters enhanced the xylanase yield from $615.5 \pm 19.21$ to $4,105 \pm$ $22 \mathrm{U} / \mathrm{g}$, suggesting the importance of the detailed bioprocess profiling. Apart from that cellulase-poor nature, high temperature, $\mathrm{pH}$ and solvent stability are suitable features for its application in paper, juice, feed improvement and in bioconversion of lignocelluloses to the solvents. The multiplicity in xylanase from $A$. tubingensis FDHN1 has been shown for the first time in the present study. Further scaling-up and purification of the xylanase still deserve more attention to reach the commercial feasibility and to find the novel properties of xylanase from this novel strain of $A$. tubingensis.

\section{Additional file}

Additional file 1: Table S1 and Figures S1 to S4. Table S1. Effect of
metals and modulators on xylanase production from A. tubingensis
FDHN1 under SSF. Figure S1. Effect of sorghum straw concentration
(3 to $15 \mathrm{~g}$ ) on xylanase production. SSF was carried out by moistening
sorghum straw with mineral salt medium $\mathrm{pH} 5.0$ at $35^{\circ} \mathrm{C}$ for 6 days.
Figure S2. Effect of xylose concentration $(0.1$ to $1.1 \%$ ) on xylanase
production. SSF was carried using $9 \mathrm{~g}$ sorghum straw under optimized
physiological conditions (at 5 days incubation, $1: 5$ (w:v) substrate:
moisture ratio, pH 6.0 and $40^{\circ} \mathrm{C}$ ). Figure S3. Effect of organic solvents
(10 to $30 \%$ ) on the xylanase activity. The crude xylanase was incubated
in the presence of various organic solvents concentration for 30 min
and at the end of reaction residual activities were measured. Figure S4.
Comparison of the un-optimized and optimized extraction conditions
on the xylanase recovery efficiency (\%). Optimized extraction conditions
were extractant/ solid ratio $12: 1$ ( $\mathrm{v}: \mathrm{w}$ ), 150 rpm agitation speed and $40^{\circ} \mathrm{C}$.
The data presented are the mean values of three replicates with the
standard deviations.




\section{Abbreviations}

SSF: solid-state fermentation; PDA: potato dextrose agar; $w / V$ : weight by volume; M: molarity; U/g: xylanase/cellulase activity as unit per gram dry substrate; U/mg: specific xylanase activity per milligram of protein; Native PAGE: native polyacrylamide gel electrophoresis; $v / w$ : volume by weight; kDa: kilodalton.

\section{Competing interests}

The authors declare that they have no competing interests.

\section{Authors' contributions}

DNA designed experiments, carried out the laboratory work and wrote the manuscript. NSB provided supervision and research direction of the experimental work, as well as editing the manuscript. HAM critically observed the results and finalized the manuscript draft. All authors contributed intellectually via scientific discussions during the study and read and approved the final manuscript.

\section{Authors' information}

DNA is registered as a Ph.D. Fellow and is also DST-INSPIRE-JRF at P. G. Department of Microbiology, Gujarat Vidyapeeth, Sadra- 382 320, Gujarat, India. NSB is a Professor at P. G. Department of Microbiology, Gujarat Vidyapeeth, Sadra- 382 320, Gujarat, India. HAM is a Reader at the Department of Life Sciences, School of Sciences, Gujarat University, Ahmadabad, Gujarat, India.

\section{Acknowledgements}

One of the authors (DNA) gratefully acknowledges the financial assistance from the Department of Science and Technology (DST), Ministry of Science and Technology, Govt. of India, for the award of Junior Research Fellowship under the INSPIRE Program during the course of the investigation. The authors would like to thank Mr. Mahesh Bhatt, Gujarat Arts \& Science College, Ahmedabad, for the language editing.

\section{Author details}

${ }^{1}$ P. G. Department of Microbiology, Gujarat Vidyapeeth, M. D. Gramseva Mahavidhyalaya, Talim Kendra Campus, Sadra 382 320, Gujarat, India. Department of Life Sciences, School of Sciences, Gujarat University, Navrangpura, Ahmedabad, Ahmedabad 380009, Gujarat, India.

\section{Received: 16 May 2014 Accepted: 11 December 2014}

\section{Published online: 11 February 2015}

\section{References}

1. Tseng MJ, Yap MN, Ratanakhanokchai K, Kyu KL, Chen ST (2002) Purification and characterization of two cellulase-free xylanases from an alkaliphilic Bacillus firmus. Enzyme Microb Technol 30:590-595

2. Collins T, Gerday C, Fellre G (2005) Xylanases, xylanase families and extremophilic xylanases. FEMS Microbiol Rev 29:3-23

3. Polizeli MLTM, Rizzatti ACS, Monti R, Terenzi HF, Jorge JA, Amori DS (2005) Xylanase from fungi: properties and industrial applications. Appl Microbiol Biotechnol 67:577-591

4. Butt MS, Tahir-Nadeem M, Ahmad Z, Sultan MT (2008) Xylanases and their applications in baking industry. Food Technol Biotechnol 46:22-31

5. Nagar S, Mittal A, Kumar D, Kumar L, Gupta VK (2012) Immobilization of xylanase on glutaraldehyde activated aluminium oxide pellets for increasing digestibility of poultry feed. Process Biochem 47:1402-1410

6. Coughlan MP, Hazlewood GP (1993) $\beta-1$, 4-D xylan-degrading enzyme systems: biochemistry, molecular biology and applications. Appl Biochem 17:259-289

7. Rao CS, Sathish T, Laxmi MM, Laxmi GS, Rao RS, Prakasham RS (2008) Modeling and optimization of fermentation factors for enhancement of alkaline protease production by isolated Bacillus circulans using feed-forward neural network and genetic algorithm. J Appl Microbiol 104:889-898

8. Gawande PV, Kamat MY (1999) Production of Aspergillus xylanase by lignocellulosic waste fermentation and its application. J Appl Microbiol 87:511-519

9. Park Y, Kang S, Lee J, Hong S, Kim S (2002) Xylanase production in solid state fermentation by Aspergillus niger mutant using statistical experimental designs. Appl Microbiol Biotechnol 58:761-766

10. Maciel GM, Vandenberghe LPS, Haminiuk CWI, Fendrich RC, Bianca BED, Brandalize TQS, Pandey A, Soccol CR (2008) Xylanase production by
Aspergillus niger LPB 326 in solid state fermentation using experimenta designs. Food Technol Biotechnol 46(2):183-189

11. Pal A, Khanum F (2010) Production and extraction optimization of xylanase from Aspergillus niger DFR5 through solid state fermentation. Bioresour Technol 101:7563-7569

12. Bailey MJ, Biely P, Poutanen K (1992) Interlaboratory testing of methods for assay of xylanase activity. J Biotechnol 23:257-270

13. Ghose TK (1987) Measurement of cellulase activities. Pure Appl Chem 59:257-268

14. Miller LG (1959) Use of dinitrosalicylic acid reagent for determination of reducing sugars. Anal Chem 31:426-428

15. Lowry OH, Rosebrough NJ, Farr AL, Randall RJ (1951) Protein measurement with Folin phenol reagent. J Biol Chem 31:426-428

16. Laemmli UK (1970) Cleavage of structural proteins during the assembly of the head of bacteriophage T4. Nature 227(5259):680-685

17. Puls J, Suhuseil J (1993) Chemistry of hemicelluloses: relationship between hemicellulose structure and enzyme required for hydrolysis, in hemicellulose and hemicellulases. Portland Press, London, pp 103-127

18. Sonia KG, Chadha BS, Saini HS (2005) Sorghum straw for xylanase hyper production by Thermomyces lanuginosus (D2W3) under solid state fermentation. Bioresour Technol 96:1561-1569

19. Betini JHA, Michelin M, Peixoto-Nogueira SC, Jorge JA, Terenzi HF, Polizeli MLTM (2009) Xylanase from Aspergillus niger, Aspergillus niveus and Aspergillus ochraceus produced under solid-state fermentation and their application in cellulose pulp bleaching. Biprocess Biosyst Eng 32:819-824

20. Pandya JJ, Gupte A (2012) Production of xylanase under solid state fermentation by Aspergillus tubingensis JP-1 and its application. Bioprocess Biosyst Eng 35:769-779

21. Goyal M, Kalra KL, Sareen VK, Soni G (2008) Xylanase production with xylan rich lignocellulosic wastes by a local soil isolate of Trichoderma viride. Braz Microbiol 39:535-541

22. Biswas R, Sahai V, Mishra S, Bisaria VS (2010) Bioprocess strategies for enhanced production of xylanase by Melanocarpus albomyces IITD3A on agro-residual extract. J Biosci Bioeng 110(6):702-708

23. Kang SW, Park YS, Lee JS, Hong SI, Kim SW (2004) Production of cellulases and hemicellulases by Aspergillus niger KK2 from lignocellulosic biomass. Bioresour Technol 91:153-156

24. Hasseltine CW (1972) Solid state fermentations. Biotechnol Bioeng 14:517-532

25. Prakasham RS, SubbaRao C, Rao RS, Rajesham S, Sarma PN (2005) Optimization of alkaline protease production by Bacillus sp. using Taguchi methodology. Appl Biochem Biotechnol 120:133-144

26. Liao H, Xu C, Tan S, Wei Z, Ling N, Yu G, Raza W, Zhang R, Xu QSY (2012) Production and characterization of acidophilic xylanolytic enzymes from Penicillium oxalicum GZ-2. Bioresour Technol 123:117-124

27. Sudan R, Bajaj BK (2007) Production and biochemical characterization of xylanase from an alkalitolerant novel species Aspergillus niveus RS2. World Microbiol Biotechnol 23:491-500

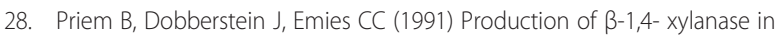
continuous culture by Aureobasidium pullulans CBS 58475. Biotechnol Lett 13:149-154

29. Lakshmi GS, Rao CS, Rao RS, Hobbs PJ, Prakasham RS (2009) Enhanced production of xylanase by newly isolated Aspergillus terreus under solid state fermentation using palm industrial waste: a statistical optimization. Biochem Eng J 48:51-57

30. Oliveira LA, Porto ALF, Tambourgi EB (2006) Production of xylanase and protease by Penicillium janthinellum CRC 87-M- 115 from different agricultural wastes. Bioresour Technol 97:862-867

31. Bakri Y, Mohammed J, Mohammed IEA (2008) Improvement of xylanase production by Cochliobolus sativus in submerged culture. Food Tehnol Biotechnol 46(1):116-118

32. Delabona PS, Pirota RDPB, Codima CA, Tremacoldi CR, Rodrigues A, Farinas CS (2013) Effect of initial moisture content on two rainforest Aspergillus strains cultivated on agro-industrial residues: biomassdegrading enzymes production and characterization. Ind Crop Prod 42:236-242

33. Lu FX, Lu M, Lu ZX, Bie XM, Zhao HZ, Wang Y (2008) Purification and characterization of xylanase from Aspergillus ficcum AF-98. Biresour Technol 99:5938-5941

34. Ogino H, Uchiho T, Yokoo J, Kobayashi R, Ichise R, Ishikawa H (2001) Role of intermolecular disulfide bonds of the organic solvent-stable PST-01 protease in its organic solvent stability. Appl Environ Microbiol 67:942-947 
35. Gupta A, Ray S, Kapoor S, Khare SK (2008) Solvent-stable Pseudomonas aeruginosa PseA protease gene: identification, molecular characterization phylogenetic and bioinformatic analysis to study reasons for solvent stability. J Mol Microbiol Biotechnol 15:234-243

36. Ines MA, Mohamed G, Ines BBR, Ali G, Hafedh B (2012) The effect of Talaromyces thermophilus cellulase-free xylanase and commercial laccase on lignocellulosic components during the bleaching of kraft pulp. Int Biodet Biodeg 75:43-48

37. Li XL, Ljungdahl LG (1994) Cloning, sequencing and regulation of a xylanase gene from the fungus Aureobasidium pullulans Y-2311-1. Appl Environ Microbiol 60:3161

38. Sharma M, Chadha BS, Saini HS (2010) Purification and characterization of two thermostable xylanases from Malbranchea flava under alkaline conditions. Bioresour Technol 101:8834-8842

39. Fernendez-Lahore HM, Fraile ER, Cascone O (1998) Acid protease recovery from a solid state fermentation system. J Biotechnol 62:83-93

40. Ghildyal NP, Ramakrishna M, Lonsane BK, Karanth NG (1991) Efficient and simple extraction of mouldy bran in a pulsed column extractor for recovery of amyloglucosidase in concentrated form. Process Biochem 26:235-241

41. Azin M, Moravej R, Zareh D (2007) Production of xylanase by Trichoderma longibrachiatum on a mixture of wheat bran and wheat straw: optimization of culture conditions by Taguchi method. Enzyme Microb Technol 40:801-805

\section{Submit your manuscript to a SpringerOpen ${ }^{\circ}$} journal and benefit from:

- Convenient online submission

- Rigorous peer review

- Immediate publication on acceptance

- Open access: articles freely available online

- High visibility within the field

- Retaining the copyright to your article

Submit your next manuscript at $>$ springeropen.com 